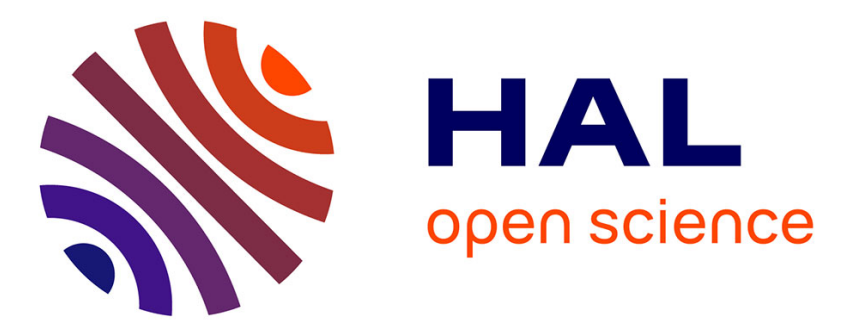

\title{
Source of the 1693 Catania earthquake and tsunami (southern Italy): New evidence from tsunami modeling of a locked subduction fault plane,
}

Marc-André M-A Gutscher, J. Roger, M.-A. Baptista, J.M. Miranda, S. Tinti

\section{- To cite this version:}

Marc-André M-A Gutscher, J. Roger, M.-A. Baptista, J.M. Miranda, S. Tinti. Source of the 1693 Catania earthquake and tsunami (southern Italy): New evidence from tsunami modeling of a locked subduction fault plane,. Geophysical Research Letters, 2006, 33, pp.L08309. 10.1029/2005GL025442 . hal-00111163

\author{
HAL Id: hal-00111163 \\ https://hal.science/hal-00111163
}

Submitted on 15 Feb 2011

HAL is a multi-disciplinary open access archive for the deposit and dissemination of scientific research documents, whether they are published or not. The documents may come from teaching and research institutions in France or abroad, or from public or private research centers.
L'archive ouverte pluridisciplinaire HAL, est destinée au dépôt et à la diffusion de documents scientifiques de niveau recherche, publiés ou non, émanant des établissements d'enseignement et de recherche français ou étrangers, des laboratoires publics ou privés. 


\title{
Source of the 1693 Catania earthquake and tsunami (southern Italy): New evidence from tsunami modeling of a locked subduction fault plane
}

\author{
M.-A. Gutscher, ${ }^{1}$ J. Roger, ${ }^{1}$ M.-A. Baptista, ${ }^{2}$ J. M. Miranda, ${ }^{2}$ and S. Tinti $^{3}$ \\ Received 9 December 2005; revised 20 February 2006; accepted 1 March 2006; published 29 April 2006.
}

[1] The 1693 Catania earthquake, which caused 60000 deaths in eastern Sicily and generated a 5-10 m high tsunami, is investigated. GPS data indicate ESE-WNW convergence in the Calabrian arc at $4-5 \mathrm{~mm} / \mathrm{yr}$. New highresolution seismic data image active compression at the toe of the accretionary wedge. The lack of instrumentally recorded thrust earthquakes suggests the presence of a locked subduction fault plane. Thermal modeling is applied to calculate the limits of the seismogenic zone. Tsunami modeling is performed to test the hypothesis that the 1693 earthquake occurred on the subduction fault plane $(160 \times$ $120 \mathrm{~km}$ in size) with $2 \mathrm{~m}$ of mean co-seismic slip. This source successfully reproduces historical observations with regard to polarity and predicts $1-3 \mathrm{~m}$ high amplitudes. It is likely that only the SW segment of the subduction fault plane ruptured in 1693 and 1169, implying a recurrence interval of roughly 500 years for similar events. Citation: Gutscher, M.-A., J. Roger, M.-A. Baptista, J. M. Miranda, and S. Tinti (2006), Source of the 1693 Catania earthquake and tsunami (southern Italy): New evidence from tsunami modeling of a locked subduction fault plane, Geophys. Res. Lett., 33, L08309, doi:10.1029/2005GL025442.

\section{Introduction}

[2] Southern Italy has been struck repeatedly by very strong historical earthquakes (Mercalli intensity IX or greater), in 1169, 1542, 1624, 1693, 1783, 1905, 1908, often associated with destructive tsunami [Piatanesi and Tinti, 1998; Jacques et al., 2001]. While several of these events, like the 1908 Messina, 1905 or 1783 Calabria earthquakes occurred along mapped, crustal, normal faults [Tinti and Piatanesi, 1996; Monaco and Tortorici, 2000; Jacques et al., 2001] the source of some of the older events remains enigmatic. Since no strong (M6) earthquakes have occurred in the past 50 years, it is difficult to identify the main active faults. The 1693 event, with maximum intensities of X to XI, caused 60,000 casualties [Piatanesi and Tinti, 1998]. Because it generated an Ambraseys-Sieberg intensity V tsunami [Tinti et al., 2004], and the isoseismals are open to the sea (Figure 1), it appears that the source region is offshore. Although its exact position remains unknown, it is of major importance for the assessment of seismic and tsunami risk in the region.

\footnotetext{
${ }^{1}$ UMR6538 Domaines Oceaniques, Institut Universitaire European De La Mer, Plouzane, France.

${ }^{2}$ Center for Geophysics, University of Lisbon, Lisbon, Portugal.

${ }^{3}$ Department of Physics and Geophysics, University of Bologna, Bologna, Italy.
}

Copyright 2006 by the American Geophysical Union. 0094-8276/06/2005GL025442\$05.00
[3] Calabria is located above a $300 \mathrm{~km}$ wide, NW dipping subduction zone which is associated with an active volcanic arc, the Aeolian Islands (Figure 1) and a well defined Wadati-Benioff zone, with earthquakes descending to nearly $500 \mathrm{~km}$ depth (Figure 2). A continuous, high Pwave velocity anomaly (slab of cold dense lithosphere) is imaged by travel-time tomography down to $660 \mathrm{~km}$ depth, where the slab flattens and underlies the western Mediterranean below Sardinia [Lucente et al., 1999; Wortel and Spakman, 2000]. It is widely accepted that Calabria has migrated SE to its current position due to a rapid roll-back of the Ionian-Tyrrhenian slab [Malinverno and Ryan, 1986; Gvirtzman and Nur, 1999; Faccenna et al., 2001] and that the high heat flow and young oceanic lithosphere in the Tyrrhenian Sea are the result of the associated back-arc extension [Zito et al., 2003].

[4] One major question, however, remains unanswered, "is the Calabria subduction zone still active"? The lack of seismicity along the subduction fault plane (with a characteristic shallow dipping thrust-type focal mechanism) implies one of three possibilities; 1) subduction has ceased, 2) subduction is active but aseismic, or 3) subduction is active and there is a large locked seismogenic zone. Highresolution seismic profiles image compressive deformation at the toe of the wedge [Hieke et al., 2005] (Figure 3). The folding of the $10 \mathrm{~m}$ thick transparent layer identified as the 3500 BP Augias Turbidite [Cita et al., 1984], indicates active shortening. Deep penetration multi-channel seismic profiles image SE vergent ramp thrusts, soling out to a regional NE dipping decollement [Cernobori et al., 1996] and offer proof that compression at the toe is tectonic in origin and not gravitational. The recent discovery of a province of mud volcanoes, indicates active dewatering in the Calabrian prism [Ceramicola et al., 2005]. If the third hypothesis is true, then Calabria may exhibit a similar behavior as the Nankai or Cascadia subduction zones, marked by long repeat times between great earthquakes on the order of hundreds of years [Hyndman and Wang, 1995; Oleskevich et al., 1999]. The purpose of this paper is to test the hypothesis of a subduction fault plane source for the 1693 Catania earthquake, using tsunami modeling.

\section{Fault Plane Geometry and Thermal Modeling}

[5] The shallow $(<20 \mathrm{~km}$ depth) geometry of the subduction fault plane is constrained by multi-channel seismic profiles, imaging a shallow NW dipping decollement $\left(<2^{\circ}\right)$, steepening somewhat $\left(>5^{\circ}\right)$ at greater depth [Cernobori et al., 1996]. The deeper geometry is obtained from the distribution of earthquake hypocenters (Figure 2).

[6] In order to determine the updip and downdip limits of the potentially seismogenic portion of the fault plane, 2-D numerical modeling of forearc thermal structure was per- 


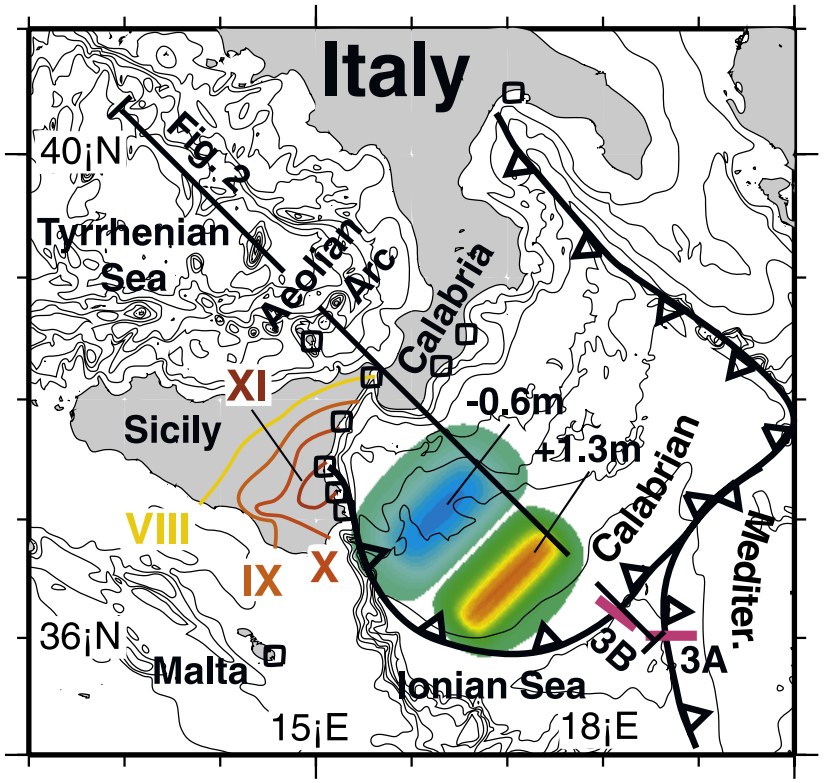

Figure 1. Location map, with proposed tsunami source. The initial vertical elastic displacement, ranging from $+1.3 \mathrm{~m}$ to $-0.6 \mathrm{~m}$, was calculated for a rectangular fault plane with dimensions of $120 \times 160 \mathrm{~km}$ and $2 \mathrm{~m}$ mean (but non-uniform) co-seismic slip. Also shown are bathymetric contours $(500 \mathrm{~m}$ interval) from the Gebco $1 \mathrm{~min}$ grid [BODC, 2003], isoseismals (contours of equal shaking intensity) of the 1693 earthquake, position of virtual mareograph stations (squares - see text for geographic names), and the position of the thermal and seismic profiles (see Figures 2 and 3).

formed [Peacock and Wang, 1999; Gutscher and Peacock, 2003]. The updip limit is commonly considered to correspond to the $100-150^{\circ} \mathrm{C}$ isotherms and the downdip limit to the $350-450^{\circ} \mathrm{C}$ isotherms [Scholz, 1990; Oleskevich et al.,

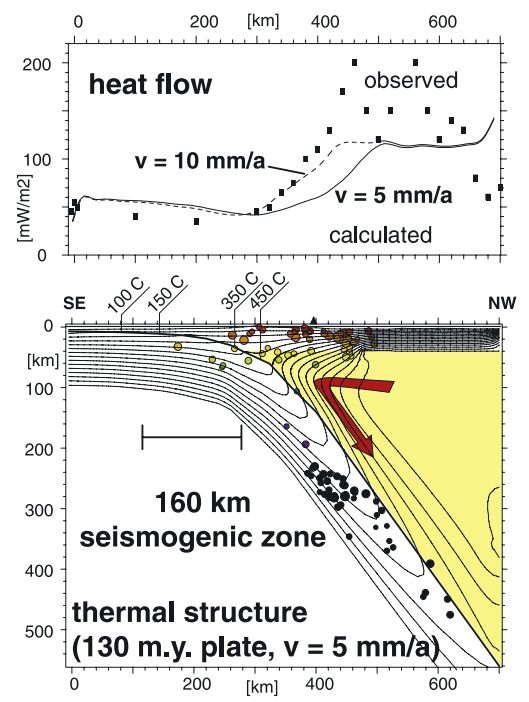

Figure 2. Thermal structure of the Calabrian arc, with the projected position of earthquakes from the relocated hypocenter catalog 1964-1995 [Engdahl et al., 1998]. The observed heat flow [Zito et al., 2003] is shown (squares) together with the calculated heat flow for two subduction velocities.

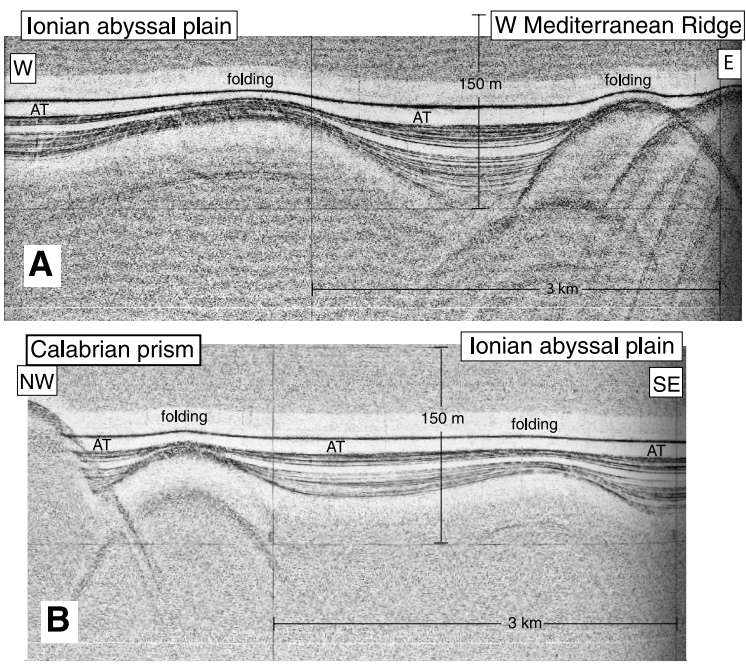

Figure 3. High-resolution $(3.5 \mathrm{kHz})$ seismic profiles from the Ionian Sea. (a) across the toe of the Western Mediterranean Ridge, (b) across the toe of the Calabrian prism. Both profiles reveal active compressional deformation and syn-tectonic sedimentation. Folding affects the uppermost turbdite layers and even disturbs the sea-floor. The 10-15 m thick transparent layer labelled AT represents the Augias Turbidite deposited as a result of the Santorini collapse of 1500 BC [Cita et al., 1984; Hieke et al., 2005].

1999]. The age of the subducting oceanic lithosphere is not well known, but the Ionian Sea is believed to be a remnant of the Tethys ocean and thus likely Jurassic in age [Faccenna et al., 2001]. An age of 130 Ma was taken. Available heat-flow data from the region show a typical forearc pattern, with low values of $50 \mathrm{~mW} / \mathrm{m} 2$ in the Ionian Sea and very high values reaching $150-200 \mathrm{~mW} / \mathrm{m} 2$ in the SE Tyrrhenian Sea, where very young oceanic lithosphere is present in the Marsili basin [Zito et al., 2003].

[7] Recent GPS measurements of the South Italian region confirm the overall NW motion of Africa with respect to Eurasia at a velocity of $5 \mathrm{~mm} / \mathrm{yr}$, as well as the SE motion of an intermediate Calabria block at $4-5 \mathrm{~mm} / \mathrm{yr}$ (in a Nubia fixed reference frame), suggesting that subduction has not ceased [D'Agostino and Selvaggi, 2004]. We calculated the thermal structure of the Calabrian arc for subduction velocities of $0-20 \mathrm{~mm} / \mathrm{yr}$. Although $10 \mathrm{~mm} / \mathrm{yr}$ provides the best fit to the observed heat-flow pattern (Figure 2), we retain the thermal structure for a velocity of $5 \mathrm{~mm} / \mathrm{yr}$ as observed by GPS. The thermally predicted downdip width of the seismogenic zone is $160 \mathrm{~km}$, spanning $120 \mathrm{~km}$ to $280 \mathrm{~km}$ from the deformation front.

\section{Fault Parameters}

[8] Very high intensities (X and XI) and a strong tsunami were reported in eastern Sicily in 1693 . However, no available historical records indicate widespread damage in Calabria, or Central Italy. Thus, it seems unlikely that the entire $300 \mathrm{~km}$ long subduction fault plane ruptured, as this would have produced a magnitude $\mathrm{Mw}=8.3$ felt over a greater distance. This is calculated, for a mean co-seismic slip of $2 \mathrm{~m}$, from the relationship $\mathrm{Mo}=\mu \mathrm{SD}$, where rigidity $\mu=3 \times 10^{10} \mathrm{~Pa}$, the rupture area $\mathrm{S}=300 \mathrm{~km} \times 160 \mathrm{~km}=48000 \mathrm{~km}^{2}$, and the slip 
$\mathrm{D}=2 \mathrm{~m}$. This yields $\mathrm{Mo}=2.88 \times 10^{21} \mathrm{Nm}$ and then using $\mathrm{Mw}=2 / 3 \log \mathrm{Mo}-6.03$, the resulting magnitude is $\mathrm{Mw}=$ 8.28. Therefore, we consider only a $120 \mathrm{~km}$ long segment, which yields a smaller magnitude of $\mathrm{Mw}=8.0$. The fault plane dips $5^{\circ}$ to the NW, extending from $5 \mathrm{~km}$ depth (shallowest) to $20 \mathrm{~km}$ depth (deepest).

[9] The mean co-seismic slip of $2 \mathrm{~m}$ is obtained by considering the recurrence interval and the subduction velocity ( $4 \mathrm{~mm} / \mathrm{yr})$. In 1169 a strong earthquake with similar intensities (X and XI) struck eastern Sicily, producing almost exactly the same isoseismal pattern [Barbano et al., 1984]. If the two earthquakes occurred along the same fault, then a recurrence time of about 500 years is implied.

\section{Tsunami Modeling}

[10] The fault parameters above were used to perform tsunami wave form modeling of a shallow NW dipping subduction source. The initial displacement of the seafloor, considered to be similar to the initial displacement of the water surface, is calculated using the elastic half-space approach [Okada, 1985]. The vertical seafloor displacement (for a pure thrust mechanism) is shown in map view and ranges from $1.3 \mathrm{~m}$ uplift to the $\mathrm{SE}$, to $0.6 \mathrm{~m}$ subsidence to the NW (Figure 1). To account for non-uniform slip within the fault plane [Geist and Dmowska, 1999], we used the smooth closure condition [Freund and Barnett, 1976] applying a skewness parameter of 0.3 and a discretization of $8 \mathrm{~km}$. For the tsunami wave propagation, finite difference software SWAN Code [Mader, 2004] was applied, using a shallow water non-linear wave model and a cell size of 0.025 degrees. The Gebco 1 min bathymetric grid was used [British Oceanographic Data Centre (BODC), 2003].

[11] Synthetic mareograms were calculated for ten stations in the southern Italy region (Figure 4). These stations were selected for the most part on the availability of historical records.

[12] They are situated along the eastern coast of Sicily (from S to N: Syracuse, Augusta, Catania, Taormina and Messina), one in the Aeolian islands (Vulcano), one on Malta, two on the SE coast of Calabria and one in the Gulf of Taranto.

[13] Synthetic mareograms provide information on wave phase, amplitude and arrival time of the tsunami wave (Figure 4). One of the most crucial observations concerning the 1693 tsunami was a strong withdrawal of the sea at all port towns of the eastern coast of Sicily which was so sudden and violent that many ships were damaged [Piatanesi and Tinti, 1998].

\section{Discussion}

[14] Previous source models for the 1693 earthquake tested primarily NE-SW trending normal faults on-land in eastern Sicily, as well as NNW-SSE trending steeply dipping normal faults offshore along the Malta escarpment [Piatanesi and Tinti, 1998; Bianca et al., 1999; Tinti et al., 2001]. None of the on-land faults tested succeeds in reproducing the observed initial withdrawal of the sea at all eastern Sicily port towns, and these must therefore be rejected as potential sources [Piatanesi and Tinti, 1998]. Along the Malta escarpment south of Syracuse, marine seismic profiles reveal no evidence of Quaternary deformation [Argnani and Bonazzi, 2005].
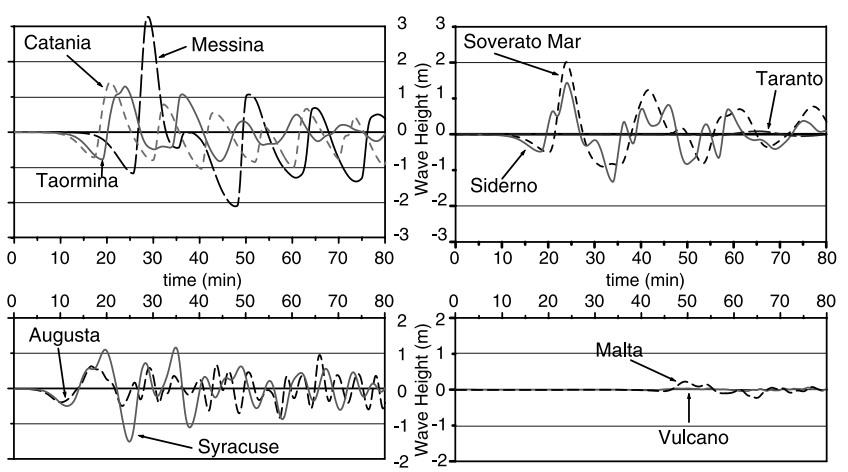

Figure 4. Synthetic mareograms calculated for the ten virtual tide gauge stations in the SE Italy region.

But the main drawback of all of these proposed sources is that unreasonably large slip values $(6-8 \mathrm{~m})$ are required [Piatanesi and Tinti, 1998; Tinti et al., 2001] to generate an earthquake of magnitude 7-7.5, with respect to the length of the fault, violating established earthquake scaling laws [Wells and Coppersmith, 1994]. The large surface area of the subduction fault generates a very strong earthquake M8.0 for only $2 \mathrm{~m}$ of co-seismic slip and is consistent with relative plate velocities $(4-5 \mathrm{~mm} / \mathrm{yr})$ and the available evidence on the recurrence interval (500 yrs). For the non-uniform slip model tested, the maximum slip is $4 \mathrm{~m}$ and thus requires portions of the fault to have accumulated a significant slip deficit during the previous seismic cycle.

[15] The subduction fault plane generates a tsunami with an initial withdrawal of the sea for all stations in eastern Sicily. Wave heights obtained, range from $1-1.3 \mathrm{~m}$ for the east coast of Sicily, with the highest amplitude $(3.3 \mathrm{~m})$ in Messina. Although this may appear small with respect to the 5-10 $\mathrm{m}$ high wave reported, these simulations do not reproduce the amplification effects from the run-up, which may increase wave heights by a factor of 2 to 5 . For instance, following the 26 December 2004 M9.3 earthquake, the tsunami amplitudes observed at tidal gauge stations in SE India (Vishakapatnam, and Tuticorin) were only $1.4 \mathrm{~m}$ (http://www.nio.org/jsp/tsunami.jsp). Likewise in Colombo (Sri Lanka) and NW Sumatra (Sibolga, Belawan) recorded wave heights were $2.1 \mathrm{~m}$ and $0.5 \mathrm{~m}$, respectively [Merrifield et al., 2005]. Yet eye-witness accounts and the physical damage in these areas indicate wave heights ranging from $5-10 \mathrm{~m}$.

[16] Calculated amplitudes for more distant stations (Vulcano, Malta or Taranto) are small $(0.1-0.25 \mathrm{~m})$. But depending on the amplification through run-up, this wave may have been noticeable. Travel-times are shortest for the east Sicily coast. The initial withdrawal would have occurred most rapidly in Syracuse and Augusta (10 min), and 15-20 min after the earthquake for Catania, and Taormina (Figure 4). The ensuing positive wave would have flooded the ports 5-10 min later. Unfortunately, no historical observations are available with regard to travel time and thus this key piece of information cannot be used to support or disprove a particular source model.

\section{Conclusion}

[17] High-resolution seismic images from the toe of the Calabrian accretionary wedge as well as recent GPS data 
indicate ongoing ESE-WNW convergence in the Calabrian arc at rates of roughly $4-5 \mathrm{~mm} / \mathrm{yr}$. The lack of instrumentally recorded thrust earthquakes supports the hypothesis of a locked subduction fault plane. For the periodicity of 500 years suggested by historical records, a mean co-seismic slip of about $2 \mathrm{~m}$ can be expected. Tsunami modeling of a subduction fault plane $(160 \times 120 \mathrm{~km}$ in size $)$ successfully reproduces the available historical observations with regard to polarity and predicts $1-3 \mathrm{~m}$ amplitudes. If this hypothesis is true, then it is likely that only the SW segment of the subduction plane ruptured in 1693 and 1169. It is unknown when the remainder of the subduction fault plane may have ruptured, yet this knowledge is crucial for estimating the seismic and tsunami hazard in the Southern Italian region.

[18] Acknowledgments. We thank the captain and crew of $\mathrm{R} / \mathrm{V}$ Atalante and I. Lefevre for acquisition of the seismic data during a transit between Istanbul and Toulon in Oct. 2002. We acknowledge financial support from INSU. This article is IUEM contribution 991.

\section{References}

Argnani, A., and C. Bonazzi (2005), Malta Escarpment fault zone offshore eastern Sicily: Pliocene-Quaternary tectonic evolution based on new multichannel seismic data, Tectonics, 24,TC4009, doi:10.1029/ 2004TC001656.

Barbano, M. S., M. T. Carrozzo, A. Chirenti, M. Cosentino, G. Lombardo, and M. Riuscetti (1984), Seismic zoning of Calabria and Sicily (south Italy), Boll. Geofis. Teor. Appl., XXVI, 39-58.

Bianca, M., C. Monaco, L. Tortorici, and L. Cernobori (1999), Quaternary normal faulting in southeastern Sicily (Italy): A seismic source for the 1693 large earthquake, Geophys. J. Int., 139, 370-394.

British Oceanographic Data Centre (BODC) (2003), Centenary Edition of the GEBCO Digital Atlas [CD-ROM], Liverpool, UK.

Ceramicola, S., D. Praeg, A. Cova, X. Monteys, V. Unnithan, S. Garziglia, and the OGS Explora Scientific Party (2005), Newly imaged mud volcanic province on the Calabrian Arc in the central Mediterranean Sea: Preliminary results from cruise HERMES-HYDRAMED IONIO 2005, Eos Trans. $A G U, 85(47)$, Fall Meet. Suppl., Abstract T13B-0455.

Cernobori, L., A. Hirn, J. H. McBride, R. Nicolich, L. Petronio, M. Romanelli, and STREAMERS/PROFILES Working Groups (1996), Crustal image of the Ionian basin and its Calabrian margins, Tectonophysics, 264, 175-189.

Cita, M. B., A. Camerlinghi, K. A. Kastens, and F. W. McCoy (1984), New findings of Bronze Age homogenites in the Ionian Sea: Geodynamic implications for the Mediterranean, Mar. Geol., 55, 47-62.

D'Agostino, N., and G. Selvaggi (2004), Crustal motion along the EurasiaNubia plate boundary in the Calabrian Arc and Sicily and active extension in the Messina Straits from GPS measurements, J. Geophys. Res., 109, B11402, doi:10.1029/2004JB002998.

Engdahl, E. R., R. D. van der Hilst, and R. Buland (1998), Global teleseismic earthquake relocation with improved travel times and procedures for depth relocation, Bull. Seismol. Soc. Am., 88, 722-743.

Faccenna, C., T. W. Becker, F. Pio Lucente, L. Jolivet, and F. Rosetti (2001), History of subduction and back-arc extension in the central Mediterranean, Geophys. J. Int., 145, 809-820.

Freund, L. B., and D. M. Barnett (1976), A two-dimensional analysis of surface deformation due to dip-slip faulting, Bull. Seismol. Soc. Am., 66, $667-675$.

Geist, E. L., and R. Dmowska (1999), Local tsunamis and distributed slip at the source, Pure Appl. Geophys., 154, 485-512.
Gutscher, M.-A., and S. M. Peacock (2003), Thermal models of flat subduction and the rupture zone of great subduction earthquakes, J. Geophys. Res., 108(B1), 2009, doi:10.1029/2001JB000787.

Gvirtzman, Z., and A. Nur (1999), The formation of Mount Etna as the consequence of slab rollback, Nature, 401, 782-785.

Hieke, W., H. B. Hirschleber, and G. A. Deghani (2005), The Ionian Abyssal Plain (central Mediterranean Sea): Morphology, subbottom structures and geodynamic history-An inventory, Mar. Geophys. Res., 24, 279-310.

Hyndman, R. D., and K. Wang (1995), The rupture zone of Cascadia great earthquakes from current deformation and the thermal regime, J. Geophys. Res., 100, 22,133-22,154.

Jacques, E., C. Monaco, P. Tapponnier, L. Tortorici, and T. Winter (2001), Faulting and earthquake triggering during the 1783 Calabria seismic sequence, Geophys. J. Int., 145, 809-820.

Lucente, F. P., C. Chiarabba, G. B. Cimini, and D. Giardini (1999), Tomographic constraints on the geodynamic evolution of the Italian region, J. Geophys. Res., 104, 20,307-20,327.

Mader, C. (2004), Numerical Modeling of Water Waves, 2nd ed., CRC Press, Boca Raton, Fla.

Malinverno, A., and W. B. Ryan (1986), Extension in the Tyrrhenian Sea and shortening in the Appenines as a result of arc migration driven by sinking of the lithosphere, Tectonics, 5, 227-245.

Merrifield, M. A., et al. (2005), Tide gauge observations of the Indian Ocean tsunami, December 26, 2004, Geophys. Res. Lett., 32, L09603, doi:10.1029/2005GL022610.

Monaco, C., and L. Tortorici (2000), Active faulting in the Calabrian arc and eastern Sicily, J. Geodyn., 29, 407-424.

Okada, Y. (1985), Surface deformation due to shear and tensile faults in a half-space, Bull. Seismol. Soc. Am., 75, 1135-1154.

Oleskevich, D. A., R. D. Hyndman, and K. Wang (1999), The updip and downdip limits to great subduction earthquakes: Thermal and structural models of Cascadia, south Alaska, SW Japan, and Chile, J. Geophys. Res., 104, 14,965-14,991.

Peacock, S. M., and K. Wang (1999), Seismic consequences of warm versus cool subduction zone metamorphism: Examples from northeast and southwest Japan, Science, 286, 937-939.

Piatanesi, A., and S. Tinti (1998), A revision of the 1693 eastern Sicily earthquake and tsunami, J. Geophys. Res., 103, 2749-2758.

Scholz, C. H. (1990), The Mechanics of Earthquakes and Faulting, 439 pp., Cambridge Univ. Press, New York.

Tinti, S., and A. Piatenesi (1996), Finite-element simulations of the 5 February 1783 Calabrian tsunami, Phys. Chem. Earth, 21, 39-43.

Tinti, S., A. Armigliato, and E. Bortolucci (2001), Contribution of tsunami data analysis to constrain the seismic source: The case of the 1693 eastern Sicily earthquake, J. Seismol., 5, 41-61.

Tinti, S., A. Maramai, and L. Graziani (2004), The new catalogue of the Italian tsunamis, Nat. Hazards, 33, 439-465.

Wells, D. L., and K. J. Coppersmith (1994), New empirical relationships among magnitude, rupture length, rupture width, rupture area, and surface displacement, Bull. Seismol. Soc. Am., 84, 974-1002.

Wortel, M. J. R., and W. Spakman (2000), Subduction and slab detachment in the Mediterranean-Carpathian region, Science, 290, 19101917.

Zito, G., F. Mongelli, S. de Lorenzo, and C. Doglioni (2003), Heat flow and geodynamics in the Tyrrhenian Sea, Terra Nova, 15, 425-432.

M.-A. Baptista and J. M. Miranda, Center for Geophysics, University of Lisbon, 1250 Lisboa, Portugal.

M.-A. Gutscher and J. Roger, UMR6538 Domaines Oceaniques, IUEM, F-29280 Plouzané, France. (gutscher@univ-brest.fr)

S. Tinti, Department of Physics and Geophysics, University of Bologna, I-40127 Bologna, Italy. 